\title{
Application of Blended Learning in the Teaching of Electronic Technology
}

\author{
Peijiang Chen \\ School of Mechanical and Vehicle Engineering \\ Linyi University \\ Linyi, China \\ Zhangmei7596@163.com \\ Hu Han \\ School of Mechanical and Vehicle Engineering \\ Linyi University \\ Linyi, China \\ Hanhu@lyu.edu.cn
}

\author{
Mei Zhang \\ Archives \\ Linyi University \\ Linyi, China \\ Zhangmei7596@163.com
}

\author{
Yujian Xie \\ School of Mechanical and Vehicle Engineering \\ Linyi University \\ Linyi, China \\ xieyujian@lyu.edu.cn
}

\begin{abstract}
Against the background of the reform of credit system, the implementation process of blended learning is explored in view of the contradiction between more content and less study time of the course of electronic technology. On the basis of analyzing the teaching requirements of the course, making full use of information technology, building and improving the network teaching platform, combining the strengths of online and offline, reforms and explorations are carried out by means of teaching contents, teaching methods and means, and learning evaluation. The application of the blended learning method cultivates students' interest and initiative in learning, and improves the teaching effect.
\end{abstract}

Keywords-Electronic technology; Blended learning; Network teaching platform; Learning evaluation

\section{INTRODUCTION}

"Electronic Technology" is a professional core course for mechanical specialties such as vehicle engineering, mechanical design, manufacturing, and automation. It is perfect in curriculum system, emphasizes practical operation, has strong engineering and comprehensive, and plays an important role in the mechanical professional system. The teaching content of the course of Electronic Technology involves two parts: analog electronics and digital electronics. The teaching content is more, and it has strong theoretical and practical. Under the background of the credit system, the classroom hours is less, which increasing the difficulty for students to learn.

At present, the main teaching mode is based on teachers, with teaching as the main means, combining with discussion and practice. As recipients of knowledge, the students participate in the teaching activities arranged by teachers [1].

This study was supported by the Education Project of Industry-university Collaboration of the Ministry of Education in 2017 (No. 201702141001), the Undergraduate Teaching Reform Project of Shandong Province Higher

Education in 2018 (No. M2018X062), and the Teaching Quality Engineering

Projects of Linyi University in 2016, 2017 and 2018.
This traditional teaching mode is not conducive to reflecting the students' dominant position in teaching, and it is difficult to stimulate students' interest in learning.

In order to improve the learning efficiency and enable students to have deeper understanding to relevant content, it is necessary to make full use of modern information technology, and adopt blended learning method in teaching. Outside the classroom teaching, using multiple teaching modes combines the advantages of traditional teaching methods with the Internet teaching.

Taking the course of "Electronic Technology" as an example, the practice of blended learning mode is used in the teaching process. In the teaching design and knowledge transfer, the teachers integrates the classroom teaching and information technology, so that the online learning and offline learning are combined organically, to achieve the studentcentered teaching model. This method can increase the participation of students, help students to focus on learning, gain deeper understanding of knowledge points, and cultivate innovative ability [2].

\section{TEACHING REQUIREMENTS OF ELECTRONIC TECHNOLOGY}

At present, the electronic technology has very extensive application and develops rapidly, and it penetrates into other disciplines and promotes there rapid development. It plays a particularly important role in economic construction of the country.

The teaching content of this course mainly includes: the basic concept of semiconductor, the circuit structure and function of amplifier circuit, the application of integrated operational amplifier, the feedback in the amplifier circuit, the function of logic gate circuit and the design of the combinational logic circuit, the structure of the trigger and the analysis of sequential logic circuits. 
Through the study of this course, students can master the basic theories, basic knowledge and basic skills necessary for electronic technology, and can use the knowledge they have learned to solve practical problems related to electronic technology. At the same time, the course can lay a good theoretical and practical foundation for the application of the electronic technology in the profession.

TABLE I. THE TEACHING CONTENTS AND CLASS REQUIREMENTS OF COURSE OF ELECTRONIC TECHNOLOGY

\begin{tabular}{|c|c|c|c|c|c|}
\hline \multirow{2}{*}{ NO. } & \multirow{2}{*}{$\begin{array}{l}\text { Teaching } \\
\text { content }\end{array}$} & \multicolumn{2}{|c|}{ Theoretical teaching } & \multicolumn{2}{|c|}{ Practical teaching } \\
\hline & & $\begin{array}{l}\text { Class } \\
\text { hours }\end{array}$ & $\begin{array}{l}\text { Teaching } \\
\text { Means }\end{array}$ & $\begin{array}{l}\text { Class } \\
\text { hours }\end{array}$ & $\begin{array}{l}\text { Teaching } \\
\text { Means }\end{array}$ \\
\hline 1 & $\begin{array}{l}\text { Semiconductor } \\
\text { diodes and } \\
\text { triodes }\end{array}$ & 6 & $\begin{array}{l}\text { Classroom } \\
\text { teaching, } \\
\text { Flipping } \\
\text { classroom, } \\
\text { Self-learning }\end{array}$ & 2 & Experiment \\
\hline 2 & $\begin{array}{l}\text { Basic } \\
\text { amplification } \\
\text { circuit }\end{array}$ & 10 & $\begin{array}{l}\text { Classroom } \\
\text { teaching, } \\
\text { Flipping } \\
\text { classroom, } \\
\text { Self-learning }\end{array}$ & 2 & Experiment \\
\hline 3 & $\begin{array}{l}\text { Integrated } \\
\text { operational } \\
\text { amplifier }\end{array}$ & 4 & $\begin{array}{l}\text { Classroom } \\
\text { teaching, } \\
\text { Flipping } \\
\text { classroom, } \\
\text { Self-learning }\end{array}$ & 2 & Experiment \\
\hline 4 & $\begin{array}{l}\text { Feedback in } \\
\text { electronic } \\
\text { circuits }\end{array}$ & 4 & $\begin{array}{l}\text { Classroom } \\
\text { teaching, } \\
\text { Flipping } \\
\text { classroom, } \\
\text { Self-learning }\end{array}$ & 2 & Experiment \\
\hline 5 & $\begin{array}{l}\text { Gate circuit } \\
\text { and } \\
\text { combinational } \\
\text { logic circuit }\end{array}$ & 12 & $\begin{array}{l}\text { Classroom } \\
\text { teaching, } \\
\text { Flipping } \\
\text { classroom, } \\
\text { Self-learning }\end{array}$ & 4 & Experiment \\
\hline 6 & $\begin{array}{l}\text { Trigger and } \\
\text { sequential } \\
\text { logic circuit }\end{array}$ & 6 & $\begin{array}{l}\text { Classroom } \\
\text { teaching, } \\
\text { Flipping } \\
\text { classroom, } \\
\text { Self-learning }\end{array}$ & 4 & Experiment \\
\hline 7 & $\begin{array}{l}\text { Memory and } \\
\text { programmable } \\
\text { logic device }\end{array}$ & 2 & $\begin{array}{l}\text { Classroom } \\
\text { teaching, } \\
\text { Flipping } \\
\text { classroom, } \\
\text { Self-learning }\end{array}$ & & \\
\hline 8 & $\begin{array}{l}\text { Analog and } \\
\text { digital } \\
\text { conversion }\end{array}$ & 4 & $\begin{array}{l}\text { Classroom } \\
\text { teaching, } \\
\text { Flipping } \\
\text { classroom, } \\
\text { Self-learning }\end{array}$ & & \\
\hline 9 & Total & 48 & & 16 & \\
\hline
\end{tabular}

The teaching requirements of this course mainly includes: understand the development status and trends of electronic technology; master the literature retrieval, data query and basic methods of using modern information technology to obtain relevant information. Can master the structure and function of semiconductor and amplifier circuit, integrate operational amplifier, feedback in amplifier circuit, function of logic gate circuit, structure of trigger, analysis of sequential logic circuit, analog-to-digital and digital-to-analog conversion. Can master the application and circuit analysis of integrated operational amplifiers, analysis and design of combinatorial logic circuits, analysis and design of sequential logic circuits, and use electronic components to build and simulate control systems.

The teaching content and class requirements of the course is given, as shown in the Table 1.

\section{CONSTRUCtion OF NETWORK TEACHING PlatForm}

Only by combining face-to-face teaching with online teaching, so that integrating the advantages of each other can obtain better learning results. Therefore, the construction of the blended learning mode must make full use of the two teaching modes and carry out comprehensive evaluation, and then improve the teaching effect significantly.

Blended learning combines network autonomous learning with classroom face-to-face learning, and effectively integrates all teaching aspects to form a coherent, multi-faceted integrated teaching system. Then, it is necessary to build a online teaching resource platform, which can provide rich learning resources, and can be served as a place for exchange between teachers and students.

The network learning platform of "electronic technology" divided into two parts, teacher platform and student platform. The student platform mainly includes teaching resources, course learning, and teaching interaction. The network teaching platform breaks through the time and space restrictions of the classroom, which makes the teachers' teaching and students' learning more comfortable [3].

TABLE II. THE MATRIX OF BLENDED TEACHING MODE

\begin{tabular}{|c|l|l|}
\hline & \multicolumn{1}{|c|}{ Online teaching } & \multicolumn{1}{c|}{ Face-to-face teaching } \\
\hline \multirow{5}{*}{ Teacher } & $\begin{array}{l}\text { Release learning task list } \\
\text { Designate learning } \\
\text { resources } \\
\text { Answer questions and } \\
\text { guide }\end{array}$ & $\begin{array}{l}\text { Listen to student reports } \\
\text { Discuss problem } \\
\text { Answer questions and guide } \\
\text { Explant knowledge point } \\
\text { Classroom assessment } \\
\text { Summary feedback }\end{array}$ \\
\hline \multirow{5}{*}{ Student } & $\begin{array}{l}\text { Receive learning tasks } \\
\text { Self-learn }\end{array}$ & $\begin{array}{l}\text { Report on learning achievements } \\
\text { Discuss problem } \\
\text { Classroom in-depth study } \\
\text { Learning exchange }\end{array}$ \\
& Summarize the learning \\
\hline
\end{tabular}

In addition, in order to successfully implement the construction of blended learning, the teachers must have certain professional knowledge and information technology literacy, they can set teaching objectives, refine knowledge points, provide course teaching videos, teaching courseware and other types of multimedia[4]. 
After build the network learning platform, a blended teaching mode matrix can be established, as shown in Table 2.

\section{PRACTICE Of Blended LeARNING IN EleCtronic TECHNOLOGY}

\section{A. Idea of Blended Learning}

The teaching object of electronic technology is for nonelectrical students such as mechanical specialties. The teaching module should be selected according to the professional needs, the practicality must be emphasized, so that the teaching content can be connected with the subsequent professional courses. Students can systematically master the basic content and analytical application of electronic technology in a limited number o hours [5].

The core of the blended teaching is that it can use the teaching design function of the system to integrate the online and offline learning according to the diverse learning needs of the learners. By blending learning resources, learning methods, teaching theories and teaching environment, teachers can play their own role in supervision and guidance in the teaching process, and cultivate students' creativity and innovation on the basis of mobilizing students' learning enthusiasm. It can deepen the learning of basic knowledge and skills, allow students to actively participate in classroom teaching, and enhance the teaching effectiveness in all aspects.

With the support of the network teaching platform, a student-centered blended learning model is adopted to organize learning activities of "online + offline". The self-learning under the information learning environment and the cooperative learning under the classroom learning environment are combined and complemented with each other to construct a new learning model that can not only play the leading role of teachers in classroom learning, but also reflect students' selflearning.

\section{B. Concrete Practice of Blended Learning}

- Pre-class study

Firstly, the teachers can use the network teaching platform of the course to send online learning notifications to students and issue task orders. Students are guided to learn independently under the guidance of the task list. The practice has proved that the purposeful learning is particularly effective.

For example, in the teaching unit of static analysis of amplifying circuit, the task list is given as shown in Table 3 . After learning independently, the students should complete the discussion and homework, and the teachers give certain grade based on the completion of the student's online learning. According to the students' discussion and homework, the teachers can determine the key content of the lectures.
TABLE III. AN EXAMPLE OF TASK LIST OF BLENDED LEARNING

\begin{tabular}{|c|l|l|l|}
\hline Unit & $\begin{array}{c}\text { Knowledge } \\
\text { point }\end{array}$ & Learning resources & \multicolumn{1}{c|}{$\begin{array}{c}\text { Discussion } \\
\text { questions }\end{array}$} \\
\hline \multirow{2}{*}{$\begin{array}{c}\text { Static } \\
\text { analysis of } \\
\text { amplifier } \\
\text { circuit }\end{array}$} & $\begin{array}{c}\text { Estimation } \\
\text { method }\end{array}$ & $\begin{array}{l}\text { Textbook: P38-39 } \\
\text { Video: Estimation } \\
\text { method to determine } \\
\text { static values }\end{array}$ & $\begin{array}{l}\text { How to draw the } \\
\text { DC path of the } \\
\text { amplifier circuit? }\end{array}$ \\
\cline { 2 - 4 } & $\begin{array}{l}\text { Graphic } \\
\text { method }\end{array}$ & $\begin{array}{l}\text { Textbook: P40-40 } \\
\text { Video: Graphical } \\
\text { method to determine } \\
\text { the static value }\end{array}$ & $\begin{array}{l}\text { What is the } \\
\text { meaning of the } \\
\text { DC load line and } \\
\text { how to draw it? }\end{array}$ \\
\hline
\end{tabular}

- Classroom teaching

In the classroom teaching process of the blended learning mode, the teachers should set teaching tasks according to the feedback of the students' online learning situation, encourage students to share their online learning experience, and highlight the students' dominant status. For example, when inviting students to analyze and exchange learning experiences, each group can randomly select a representative to speak. The students discuss according to the exchanged content. The exchange results can be served as grade of all the students in the group. This measure can promote the mutual learning among students in the group.

- After-class expansion

For students, the after-class links can help them to absorb knowledge points, and also help to study the next knowledge point. The network teaching platform can create wrong question database, knowledge point problem database, and learning resource library. For teachers, they can adjust the teaching content and teaching progress according to the online and classroom teaching links, so as to better implement the teaching. Then, the blended learning is a dynamic and constantly changed model.

\section{Assessment Methods OF BLENDED LEARNING}

The curriculum assessment is an important part of teaching activities. The key to the reform of the curriculum-based teaching model is the reform of the examination methods of the curriculum.

Because the blended learning is divided into multiple links, the students' learning evaluation also adopts a blended evaluation method, which combines the students' selfevaluation, mutual evaluation and teacher evaluation, and combines the process evaluation and the final evaluation.

According to the nature of Electronic Technology and the requirements of the syllabus, the course assessment aims to stimulate students' self-learning potential and evaluate students objectively. Therefore, the assessment method focuses on the two important environments of online and offline. The processes and outcomes are equally important, and the personal ability, team scores and other comprehensive factors should be considered [6].

The assessment is divided into three parts: the final exam paper, the process assessment and the study notes. The final exam paper can not only examine students' understanding and 
mastery of the basic theories and basic knowledge of the course but also comprehensively examine students' comprehensive application ability of various knowledge points and the ability to analyze problems using basic principles.

The process evaluation mainly includes the following items: attendance, experiment, and application of online course platform. In particular, the latter occupies a high percentage, the examination includes self-learning, material utilization, discussion, activity, and so on.

\section{CONCLUSIONS}

With the rapid development of higher education informatization, the blended learning has been paid more and more attention in the field of education. It combines the advantages of traditional teaching methods with the advantages of digital teaching, which not only plays a guiding role for teachers, but also enhances the initiative of students. In the process of the course teaching, it can change the traditional teaching mode, adopt a variety of teaching modes to improve teaching quality, then the new teaching method has a strong research significance.

According to the talents training requirements of mechanical specialties and the characteristics and current situation of the teaching of Electronic Technology, combined with the informationization teaching reform being carried out by the school, it is necessary and feasible to carry out the research and practice of blended learning for the course of Electronic Technology. The blended learning mode can combine traditional teaching and online teaching organically to achieve good interaction between teachers and students in the classroom, online and offline, which can improve the teaching effect of the course of Electronic Technology.

\section{ACKNOWLEDGMENT}

This study was supported by the Education Project of Industry-university Collaboration of the Ministry of Education in 2017 (No. 201702141001), the Undergraduate Teaching Reform Project of Shandong Province Higher Education in 2018 (No. M2018X062), and the Teaching Quality Engineering Projects of Linyi University in 2016, 2017 and 2018.

\section{REFERENCES}

[1] X. Chen, Application of Blending Teaching Model based on Flipped Classroom: Taking Digital Electronic Technology and Application as Example, China Educational Technique \& Equipment. (12) (2017) 129131.

[2] J. Li, Z. Li, Y. Peng, Blending Learning Teaching in Digital Electronic Technology Course, Education Teaching Forum. (4) (2018) 175-176.

[3] L. Wang, Discussion on Blended-learning of Analog Electronic Technology, Education Teaching Forum. (49) (2016) 89-90.

[4] Q. Zhang, A. Wang, The Design of New Blended Learning Model Based on Flipped Classroom, Modern Education Technology. 24, (4) (2014) 27-32.

[5] W. Cai, Z, Zhang, L. Chen, X. Liu, Research of Blended learning in the Teaching of Electrical and Electronic Technology, Journal of Science of Teachers' College and University. 35, (3) (2015) 83-86.

[6] Z. Wang, Z. Tang, H. Liu, Research and Practice of Hybrid Teaching Method in the Course of Electronic Technology in Higher Vocational Education, Wireless Internet Technology. (22) (2016) 68-69. 